\title{
Effect of Activities at the Gboko Abattoir on Some Physical Properties and Heavy Metals Levels of Surrounding Soil
}

\author{
S. T. Ubwa ${ }^{1}$, G. H. Atoo ${ }^{1}$, J. O. Offem ${ }^{2}$, J. Abah ${ }^{1} \&$ K. Asemave ${ }^{1}$ \\ ${ }^{1}$ Department of Chemistry, Benue State University, Makurdi, Nigeria \\ ${ }^{2}$ Department of Pure and Applied Chemistry, University of Calabar, Calabar, Nigeria \\ Correspondence: G. H. Atoo, Department of Chemistry, Benue State University, P.M.B 102119, Makurdi, \\ Nigeria. Tel: 234-806-782-1341. E-mail: ghatoo@yahoo.com
}

\author{
Received: November 21, 2012 Accepted: December 31, $2012 \quad$ Online Published: January 22, 2013 \\ doi:10.5539/ijc.v5n1p49 \\ URL: http://dx.doi.org/10.5539/ijc.v5n1p49
}

\begin{abstract}
The study determined the levels of some heavy metals and $\mathrm{pH}$, organic matter and particle size distribution of soil within the vicinity of Gboko abattoir. Soil samples were collected at depth of $0-20 \mathrm{~cm}$ and analyzed using standard laboratory methods. The results of AAS analysis of the heavy metals showed that the soil had mean value of $\mathrm{Zn}^{2+} 3.0195 \mathrm{ppm}, \mathrm{Pb}^{2+} 0.5413 \mathrm{ppm}, \mathrm{Ni}^{2+} 0.1949 \mathrm{ppm}, \mathrm{Cr}^{3+} 0.1134 \mathrm{ppm}$ and $\mathrm{Cd}^{2+} 0.0185 \mathrm{ppm}$. These values were higher than similar results obtained from the control soil but the mean levels of the metals were lower than the permissible limits set by the Nigerian Department of Petroleum Resources (NDPR) and European Union (EU) respectively. The soil heavy metals were positively correlated. The mean $\mathrm{pH}$ of the soil (6.03) indicates acidity, the organic matter was very high and the particle size distribution revealed sandy-loam texture. The results of the analysis showed some levels of pollution which indicated that the activities at the abattoir were contributing to the pollution load of soil in the environment. It is therefore, recommended that the activities at the abattoir should be monitored closely by relevant agencies in order to prevent full-blown environmental problems in the near future and avert the attendant health hazards.
\end{abstract}

Keywords: abattoir, soil pollution, heavy metals, environment, physico-chemical parameters

\section{Introduction}

Almost all industries in Nigeria generate wastes which, in most cases, are disposed of without due regard to sound environmental management practices. This practice is common with small scale and even some large scale industries. Most of wastes generated are either useful or harmful to humans. Most wastes especially the solids are carried to the rivers and streams through surface runoffs while some drain into the soil. In many parts of the world, human activities such as animal production and meat processing impact negatively on soil and natural water composition. This leads to pollution of such soils, natural water resources and the entire environment (Adesemoye et al., 2006). Meat processing is usually carried out in a specialized environment known as abattoir or slaughter house. An abattoir is a place or building where animals are killed for their meat (Hornby, 2006). Abattoir can also be defined as premises approved and registered by regulatory authorities for hygienic slaughtering, inspections, processing, effective preservation and storage of meat products for human consumption (Alorge, 1992). The major activities involved in the operations of an abattoir are: receiving and holding of livestock; slaughter and carcass dressing of animals; chilling of carcass products; carcass boning and packaging; freezing of finished carcass and cartooned product; rendering processes; drying of skins; treatment of wastes and transport of processed material. However, meat processing activities in Nigeria are mostly carried out in unsuitable buildings and by untrained personnel or butchers who are mostly unaware of sanitary principles (Olanike, 2002). Abattoir activities are aimed at optimizing the recovery of edible portions of the meat processing cycle for human consumption. However, significant quantities of secondary waste materials; blood, fat, organic and inorganic solids, salts and chemicals wastes are also generated during this process (Red Meat Abbattoir Association, 2010; Steffen, Roberts and Kirsten Inc., 1989). Various organs of cattle such as: muscle, blood, liver, kidney, viscera and hair have been found to contain heavy metals (Kruslin et al., 1999; Jukna, 2006). In ruminants, the first stomach or paunch contains undigested materials called paunch manure, which can contain long hairs, whole grain and large plant fragments. The faeces of livestock (animal manure) consist of undigested food, mostly cellulose-fibre, undigested protein, excess nitrogen from digested protein, residue from digested 
fluids, waste mineral matter, worn-out cells from intestinal linings, mucus, bacteria, and foreign matter such as dirt consumed, calcium, magnesium, iron, phosphorous, sodium, etc (Ezeoha et al., 2011). Abattoir effluent wastewater has a complex composition and can be very harmful to the environment. For example, discharge of animal blood into streams would deplete the dissolved oxygen (DO) of the aquatic environment. Improper disposal of paunch manure may exert oxygen demand on the receiving environment or breed large population of decomposers (micro-organisms) which may be pathogenic. Furthermore, improper disposal of animal faeces may cause oxygen-depletion in the receiving environment. It could also lead to nutrient-over enrichment of the receiving system and increase rate of toxins accumulation in biological systems (Nwachukwu et al., 2011). Mohammed et al. (2012) reported that the improper disposal of abattoir effluent could lead to transmission of pathogens to human which may cause outbreaks of water borne diseases e.g. diarrhea, pneumonia, typhoid fever, asthma, wool sorter diseases, respiratory and chest diseases, etc. Studies have shown that $E$. coli infection source was reported to be from undercooked beef which had been contaminated, in abattoirs, with faeces containing the bacterium (Bello et al., 2009). It had also been reported that abattoir activities were responsible for the pollution of surface and underground waters, air quality as well as reduction quality of health of residents within the surrounding environment (Patra et al., 2007; Katarzyna et al., 2009; Odoemelan \& Ajunwa, 2008). This study is therefore aimed at analysis the effects of the activities at Gboko abattoir on the surrounding soil. The results will create public awareness about the state and health implications of abattoir activities on the environment.

\section{Materials and Methods}

\subsection{The Study Area}

Gboko is one of the largest and most populous Local Government Areas in Benue State. It has a land mass of $2,645 \mathrm{~km}^{2}$ with a population of 298,387 people according to Nigeria's National Population Commission census of 1990. It is bounded by Tarka Local Government on the North, Ushongo Local Government to the south, Buruku Local Government on the east, Gwer on the west and Konshisha Local Government on the south west. It lies between latitude $7^{\circ} 05^{\prime}-7^{\circ} 31^{\prime} \mathrm{N}$ and longitude $9^{\circ} 13^{\prime}-9^{\circ} 35^{\prime} \mathrm{E}$ in the savannah region of Nigeria with typical savannah vegetation and climate. The integrated Gboko abattoir is located along km8 Gboko-Aliade road and close to a stream that flows into Ushongo LGA. Several animals (cows, goats, sheep and pigs) are slaughtered everyday in this abattoir. Normal abattoir operations however are carried out every week (Monday to Saturday) during the morning hours.

\subsection{Sampling}

Six sampling stations (AS, BS, CS, DS, ES, and FS) where mapped out around the abattoir at a distance of $50 \mathrm{~m}$ from each other. Composite soil samples were collected at depth of $0-20 \mathrm{~cm}$ using soil auger (Odoemelan \& Ajunwa, 2008). The samples were collected between July and August, 2011 at an interval of ten days beginning from July 1, 2011. A control soil was also collected $60 \mathrm{~m}$ north of the abattoir during the sampling period. A total of forty-two composite soil samples were collected across the sampling points, packed in labeled polythene and conveyed to laboratory for preparation and analysis.

\subsection{Sample Preparations}

The soil samples were air-dried to constant weight at room temperature, ground separately in a porcelain mortar and sieved through a $0.063 \mathrm{~mm}$ nylon sieve. A $1.0 \mathrm{~g}$ of each soil samples was weighed into a $100 \mathrm{~mL}$ beaker and $10 \mathrm{~mL}$ of concentrated nitric acid was added. This was heated to dryness. Then, $10 \mathrm{~mL} 16 \mathrm{M} \mathrm{HNO}_{3}$ and $3 \mathrm{~mL}$ $11 \mathrm{M} \mathrm{HClO}_{4}$ were added and the solution heated to fuming after which the residue was dissolved with $4 \mathrm{~mL}$ of hot $6 \mathrm{M} \mathrm{HCl}$, filtered and diluted with distilled water to $100 \mathrm{~mL}$ (Allen et al., 1974). A reagent blank solution was also prepared using the same procedure.

\subsection{Analysis of the Samples Digests}

Samples digests were analyzed for the levels of $\mathrm{Cd}^{2+}, \mathrm{Zn}^{2+}, \mathrm{Ni}^{2+}, \mathrm{Cr}^{3+}$, and $\mathrm{Pb}^{2+}$ using Atomic Absorption Spectrophotometer (AA 6800) at National Research Institute for Chemical Technology (NARICT), Zaria, Nigeria.

\subsection{Determination of $\mathrm{pH}$ and Temperature}

The $\mathrm{pH}$ of the soil was determined using soil to water ratio of 1:1, $10.0 \mathrm{~g}$ of the air-dried, ground soil sample was weighed into a $50 \mathrm{~mL}$ plastic beaker and $10 \mathrm{~mL}$ of distilled water was added, stirred gently and allowed to stand undisturbed for 30 minutes. Then, the $\mathrm{pH}$ meter was calibrated using buffer 4, 7 and 9 after which the electrode was immersed into the soil suspension and the $\mathrm{pH}$ read after 30 seconds. Temperature was taken at the same time using pH meter temperature probe (Natural Resources Conservation Service [NRCS], 2011). 


\subsection{Determination of Organic Matter}

The method of Walkley and Black (1934) was used to determine the soil Organic Matter. A $1.0 \mathrm{~g}$ of soil was weighed into a $250 \mathrm{~mL}$ Erlenmeyer flask and $10 \mathrm{~mL}$ of $0.167 \mathrm{M} \mathrm{K}_{2} \mathrm{Cr}_{2} \mathrm{O}_{7}$ was added using a pipette and then

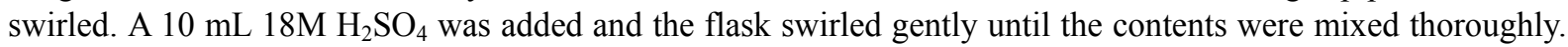
Thereafter, it was swirled more vigorously for one minute and allowed to stand for 30 minutes. Then $100 \mathrm{~mL}$ of distilled water was added and allowed to cool. Furthermore, 4-5 drops of ferroin indicator were added and titrated against $0.5 \mathrm{M}$ iron (II) ammonium sulphate solution. Blank determinations were similarly made and Percentage organic matter was calculated using the following formulae;

$$
\begin{gathered}
\text { Organic Carbon } \%=\frac{\text { Blank titre - Actual titre }}{\text { Weight of air dry soil taken }} \times 0.003 \times \mathrm{M} \times \mathrm{F} \times 100 \\
\text { Organic matter } \%=\% \text { Organic carbon } \times \frac{1.724}{0.58}
\end{gathered}
$$

Where $\mathrm{F}=$ Correction factor $=1.33, \mathrm{M}=$ Concentration of ferrous ammonium sulphate.

\subsection{Determination of Soil Particle Size}

The soil particle size was determined using the improved Hydrometer Method as described by Ibitoye (2006). A $50.0 \mathrm{~g}$ of $2 \mathrm{~mm}$ sieved soil sample was weighed into a $250 \mathrm{~mL}$ plastic beaker. Then, $100 \mathrm{~mL}$ of $5 \% \mathrm{w} / \mathrm{v}$ calgon solution (sodium hexametaphosphate), $\left(\mathrm{NaPO}_{3}\right)_{6}$ was added and stirred with glass rod. Then, about $100 \mathrm{~mL}$ of distilled water was added, stirred and the beaker allowed standing for 30 minutes with occasional stirring. Thereafter, the sample was transferred into a mixing cup and stirred for five minutes after which it was transferred into a $250 \mathrm{~mL}$ plastic container and shaken on an end to end shaker for ten minutes. The mixture was transferred into a $1000 \mathrm{~mL}$ measuring cylinder and filled up to the mark with distilled water. The suspension was mixed vigorously using a long handle plunger to ensure that the sediment at the bottom was thoroughly agitated disturbed before starting the hydrometer reading. The hydrometer was lowered into the suspension and readings taken after 40 seconds with the corresponding temperature. After 2 hours, the hydrometer was again lowered into the suspension and readings taken at the top of the meniscus and temperature was also recorded. A blank solution was prepared by making $100 \mathrm{~mL}$ of $5 \% \mathrm{w} / \mathrm{v}$ calgon solution and made up to one litre with distilled water and the readings taken as previously done. The corrected hydrometer readings $\mathrm{C}(\mathrm{g} / \mathrm{L})$ were obtained by subtracting the blank reading $\mathrm{R}_{\mathrm{L}}(\mathrm{g} / \mathrm{L})$ from the hydrometer readings in the soil suspensions $\mathrm{R}(\mathrm{g} / \mathrm{L})$ and adding $0.36 \mathrm{~g} / \mathrm{L}$ for every degree above $20{ }^{\circ} \mathrm{C}$ :

$$
\mathrm{C}=\mathrm{R}-\mathrm{R}_{\mathrm{L}}+(0.36 \mathrm{~T})
$$

Where $\mathrm{T}=$ Room Temperature.

The percentages by weight of silt, clay and sand fractions were calculated as follows:

$$
\begin{gathered}
\% \text { Clay }=\frac{\text { Corrected two hours reading - blank }}{\text { Weight of soil taken }} \times 100 \\
\% \text { Silt }=\frac{\text { Corrected } 40 \text { secs. reading }- \text { blank }-\% \text { Clay }}{\text { Weight of soil taken }} \times 100 \\
\% \text { Sand }=100-\% \text { clay }+ \text { silt }
\end{gathered}
$$




\section{Results and Discussion}

The results are presented in Tables $1-3$ and Figure $2-4$ as follows:

Table 1. Heavy metals level (ppm) in soils around the vicinity of the Gboko Abattoir

\begin{tabular}{lccccc}
\hline Sampling Point & & \multicolumn{4}{c}{ Metal } \\
& $\mathrm{Cd}^{2+}$ & $\mathrm{Zn}^{2+}$ & $\mathrm{Ni}^{2+}$ & $\mathrm{Cr}^{3+}$ & $\mathrm{Pb}^{2+}$ \\
\hline AS & $0.0035 \pm 0.00290$ & $2.3765 \pm 0.0130$ & $0.0781 \pm 0.0730$ & $0.0717 \pm 0.0303$ & $0.3634 \pm 0.1783$ \\
BS & $0.0110 \pm 0.0068$ & $1.1818 \pm 0.6656$ & $0.1999 \pm 0.1030$ & $0.1007 \pm 0.0356$ & $0.1854 \pm 0.1783$ \\
CS & $0.0720 \pm 0.0151$ & $5.1523 \pm 0.6068$ & $0.2860 \pm 0.0262$ & $0.1170 \pm 0.0267$ & $1.6757 \pm 0.0105$ \\
DS & $0.0098 \pm 0.0009$ & $5.2362 \pm 0.0008$ & $0.3032 \pm 0.1030$ & $0.1358 \pm 0.0214$ & $0.2077 \pm 0.1049$ \\
ES & $0.0079 \pm 0.0064$ & $4.0943 \pm 0.1294$ & $0.2039 \pm 0.0300$ & $0.1270 \pm 0.0373$ & $0.3114 \pm 0.0839$ \\
FS & $0.0066 \pm 0.0053$ & $1.1302 \pm 0.2003$ & $0.0980 \pm 0.0037$ & $0.1283 \pm 0.0214$ & $0.5042 \pm 0.1888$ \\
GS (ctrl) & $0.0021 \pm 0.0007$ & $0.2037 \pm 0.0102$ & $0.0070 \pm 0.0021$ & $0.0562 \pm 0.0234$ & $0.0010 \pm 0.0032$ \\
MEAN & $0.0185 \pm 0.0028$ & $3.0195 \pm 0.3201$ & $0.1949 \pm 0.0240$ & $0.1134 \pm 0.1701$ & $0.5413 \pm 0.1083$ \\
RANGE & $0.0035-0.0720$ & $1.1302-5.2362$ & $0.0781-0.3032$ & $0.0717-0.1358$ & $0.1854-1.6757$ \\
\hline
\end{tabular}

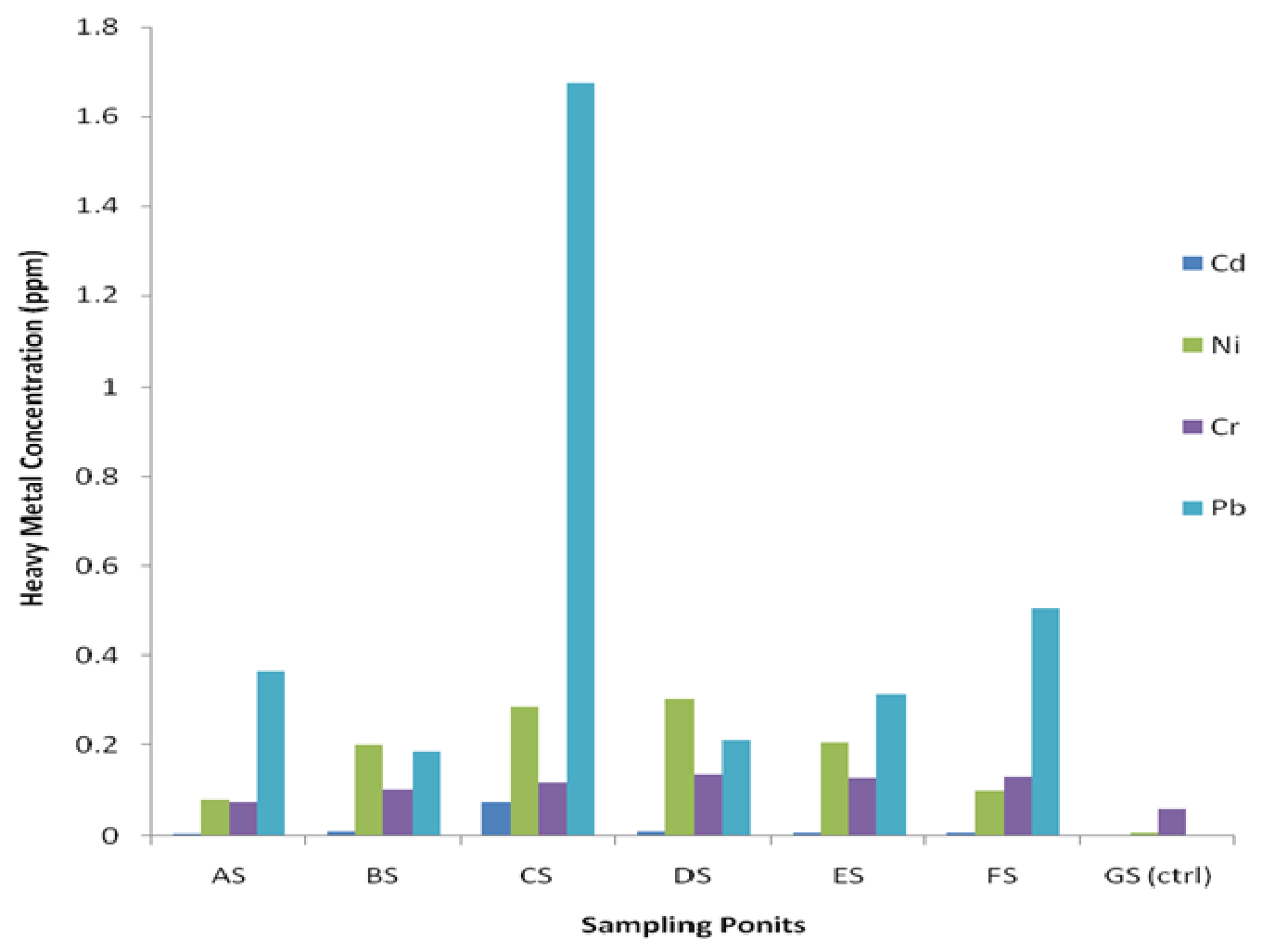

Figure 2. Mean concentration (ppm) of heavy metals in soil in the vicinity of Gboko Abatttoir 


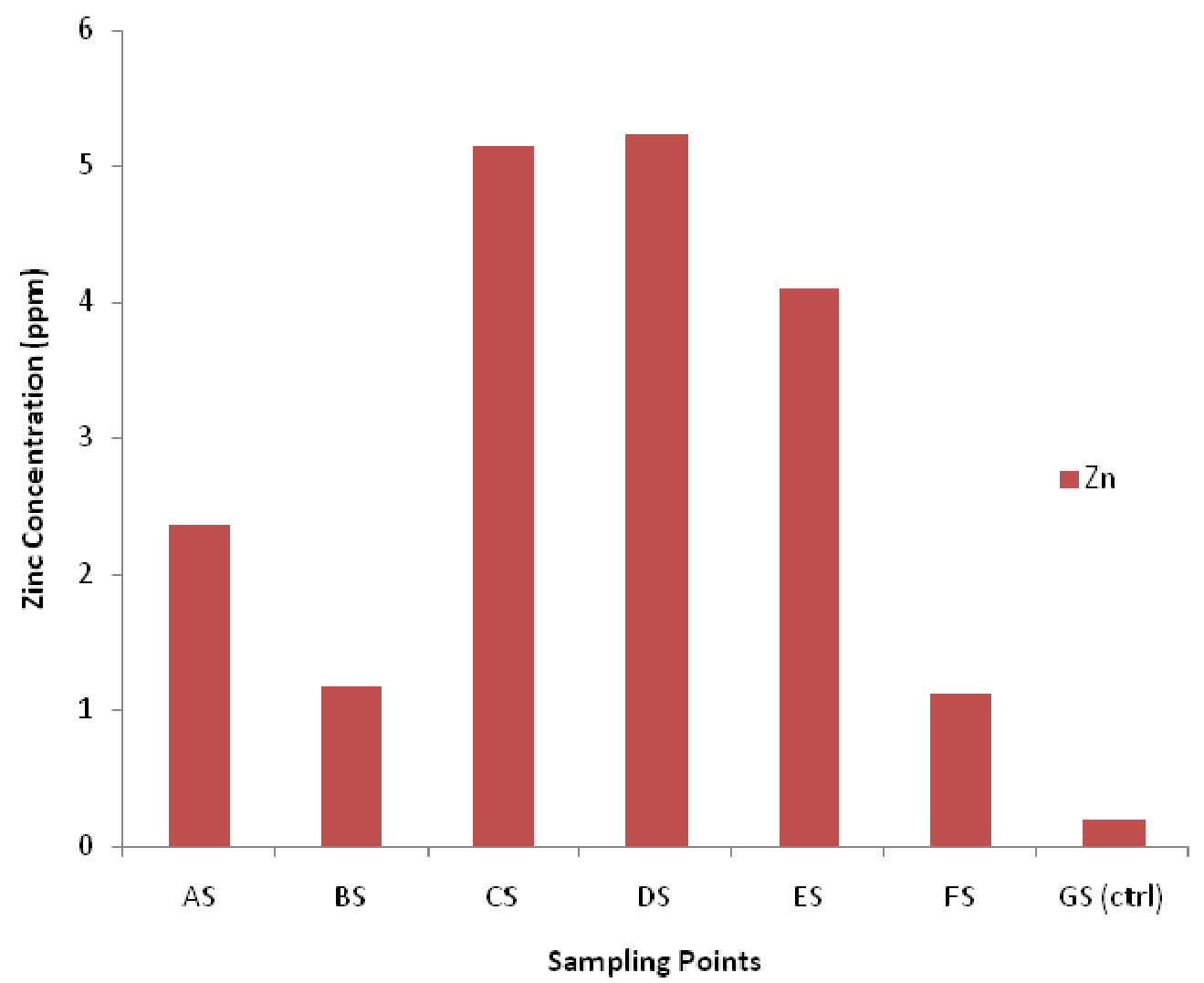

Figure 3. Mean concentration (ppm) of zinc in Abattoir soil

Table 1 and Figures 2 and 3 show results of the levels of some heavy metals in soil at the various sampling stations. The analysis was restricted to the top soil $(0-20 \mathrm{~cm})$ since it has been reported that surface soils are better indicators of metallic load (Adriano et al., 2003). Differences in metal concentrations across the sampling stations and that of the control area were also recorded. Zinc was the most abundant metal recorded (Figure 3) with range between $1.1302-5.2362 \mathrm{ppm}$ followed by $\mathrm{Pb}$ with a range between $0.1854-1.6757 \mathrm{ppm}$. The mean concentrations of the metals were observed to be 3.0195 and $0.5413 \mathrm{ppm}$ respectively. $\mathrm{Cd}^{2+}, \mathrm{Ni}^{2+}$ and $\mathrm{Cr}^{3+}$ have ranges from $0.0035-0.0720,0.0781-0.3032$ and $0.0717-0.1358 \mathrm{ppm}$ respectively. Cd was the least in terms of abundance. In general, metal abundance was observed to be in the order $\mathrm{Zn}^{2+}>\mathrm{Pb}^{2+}>\mathrm{Ni}^{2+}>\mathrm{Cr}^{3+}>\mathrm{Cd}^{2+}$. The concentrations of metals in the soil under study were generally higher than their control indicating some degree of contamination;

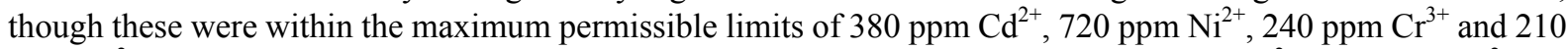
ppm $\mathrm{Pb}^{2+}$ of Nigeria's Department of Petroleum Resources (DPR) (2002) and $3.0 \mathrm{ppm} \mathrm{Cd}^{2+}, 300 \mathrm{ppm} \mathrm{Zn}^{2+}, 75$ ppm $\mathrm{Ni}^{2+}, 150 \mathrm{ppm} \mathrm{Cr}^{3+}$ and $300 \mathrm{ppm} \mathrm{Pb}^{2+}$ of European Union (EU) (2001). Unlike organic contaminants which are oxidized to carbon (IV) oxide by microbial action, most metals do not undergo microbial or chemical degradation, therefore, their total concentration in soils persists for a long time after introduction (Agyarko et al., 2010; Okoronkwo et al., 2006). However, changes in their chemical forms and bioavailability are possible. Their persistence in soil may lead to increase up-take by plants and vegetables grown in the area. This will subsequently lead to increased risk of transfer through food chain and their possible accumulation in the human tissue to lethal concentration over time is a thing of concern.

The health implications of elevated levels of zinc $\left(\mathrm{Zn}^{2+}\right)$ are severe vomiting, diarrhea, bloody urine, liver and kidney failure and anemia (Fosmire, 1990). Lead $\left(\mathrm{Pb}^{2+}\right)$ poison causes inhibition of hemoglobin synthesis; dysfunction in the kidneys, reproductive systems and cardiovascular system (Ferner, 2001). Other effects of lead poison are damage to gastro-intestinal system, mental retardation in children, abnormalities in fertility and pregnancy (Dara, 2000). It is being found that excess $\mathrm{Cd}^{2+}$ can bring about renal dysfunction, anemia, hypertension, bone marrow disorder and cancer. Others are kidney damage, bronchitis, gastric and intestinal disorders, liver and brain disorders (Dara, 2000). Consequences of the exposure to $\mathrm{Cr}^{3+}$ beyond the permissible limits may include; irritation, dermatitis and ulceration of the skin, perforation of nasal septum etc (Dara, 2000). $\mathrm{Ni}$ can cause respiratory disorders, dermatitis, cancer of the lungs and sinus, and carcinogenicity (Dara, 2000). 
Table 2. Mean physicochemical properties of soils around the vicinity of the Gboko Abattoir

\begin{tabular}{lcccccc}
\hline \multirow{2}{*}{$\begin{array}{c}\text { Sampling } \\
\text { Point }\end{array}$} & \multicolumn{5}{c}{ Soil Parameter (physico-chemical parameter) } \\
\cline { 2 - 7 } & Temp $\left({ }^{\circ} \mathrm{C}\right)$ & $\mathrm{pH}$ & $\%$ Sand & \% Silt & \% Clay & \% Organic Matter \\
\hline AS & $31.90 \pm 0.64$ & $6.06 \pm 0.00$ & $75.24 \pm 1.41$ & $13.92 \pm 0.91$ & $10.84 \pm 0.51$ & $7.11 \pm 0.38$ \\
BS & $31.05 \pm 0.07$ & $4.99 \pm 0.502$ & $68.16 \pm 2.94$ & $17.56 \pm 6.28$ & $14.28 \pm 3.34$ & $5.57 \pm 0.71$ \\
CS & $31.70 \pm 1.13$ & $5.43 \pm 0.83$ & $64.16 \pm 3.73$ & $20.56 \pm 2.83$ & $15.28 \pm 6.56$ & $12.62 \pm 0.54$ \\
DS & $30.95 \pm 1.06$ & $6.39 \pm 0.88$ & $62.14 \pm 3.71$ & $22.58 \pm 0.03$ & $15.28 \pm 3.73$ & $24.13 \pm 0.64$ \\
ES & $31.65 \pm 0.07$ & $6.73 \pm 0.45$ & $67.44 \pm 0.91$ & $19.64 \pm 0.91$ & $12.92 \pm 1.41$ & $18.59 \pm 0.43$ \\
FS & $31.45 \pm 0.07$ & $6.59 \pm 0.04$ & $67.44 \pm 0.91$ & $20.00 \pm 2.83$ & $12.56 \pm 0.91$ & $7.68 \pm 0.11$ \\
GS (ctrl) & $31.60 \pm 0.42$ & $6.44 \pm 0.17$ & $68.16 \pm 0.91$ & $18.64 \pm 1.92$ & $13.30 \pm 1.02$ & $3.00 \pm 0.00$ \\
MEAN & $31.45 \pm 0.65$ & $6.03 \pm 0.51$ & $67.43 \pm 2.30$ & $19.04 \pm 3.09$ & $13.53 \pm 3.20$ & $12.62 \pm 0.57$ \\
RANGE & $30.95-31.90$ & $4.99-6.73$ & $62.14-75.24$ & $13.92-22.58$ & $10.84-15.28$ & $5.57-24.13$ \\
\hline
\end{tabular}

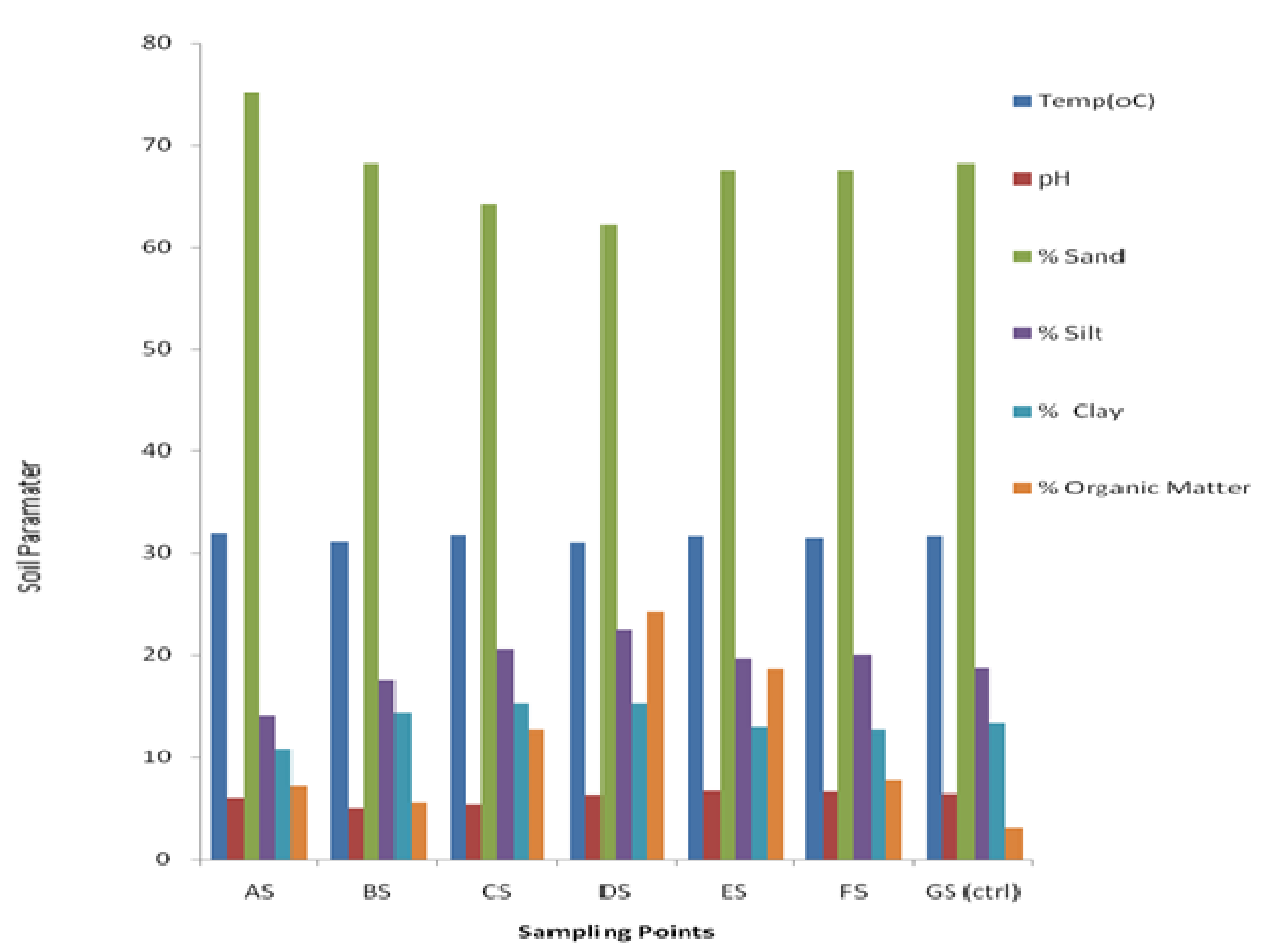

Figure 4. Mean physicochemical properties of soil around the vicinity of Gboko Abattoir

Table 2 and Figure 4 show the mean values of some physiochemical parameters of the soil investigated. The soil temperature was found to range from $30.95-31.90{ }^{\circ} \mathrm{C}$. The soil $\mathrm{pH}$ ranges from $4.99-6.73$ with a mean $\mathrm{pH}$ value of 6.03 indicating that the soil is slightly acidic in nature. This value is lower than the control (6.44) and compares well with 5.8-6.4 reported by David et al. (2009). It is also lower than 6.8-7.5 and 6.9 reported by Agyarko et al. (2003) and Okoronkwo et al. (2006) respectively. At low pH (acidic), metals are more soluble in the soil solution; hence toxicity problems are more severe than alkaline soils. The textural class of the soil is a sandy loam with a mean sand proportion of $67.43 \%, 19.04 \%$ silt and $13.53 \%$ clay. The sandy nature of the soil makes it highly permeable and allows large quantities of leachate to pass through, thereby having a potential of 
polluting the surrounding underground water. The result of the analysis on textural class is in line with that on the organic matter because sandy soils have low organic matter content and those high in clay and silt are generally higher in soil organic matter. The percentage organic matter ranges from $5.57-24.12 \%$ with a mean value of $12.62 \%$, this is higher than its control. The higher value may have been resulted from the decomposition and composting processes of the animals waste such as animal dung, body parts and blood. The result of organic matter agrees with the reported $\mathrm{pH}$ range of 6.0-7.0 for mineral soil and 5.0-5.5 for organic soils (David, 2009). Organic matter plays an important role in soil structure, water retention, cation exchange and in the formation of complexes (Alloway \& Ayres, 1997). Organic matter and $\mathrm{pH}$ are the most important parameters controlling the accumulation and availability of heavy metals in soil environment (David, 2009).

Table 3. Correlation Matrix for pairs of the analyzed elements in the soil

\begin{tabular}{llllll}
\hline & $\mathrm{Cd}^{2+}$ & $\mathrm{Zn}^{2+}$ & $\mathrm{Ni}^{2+}$ & $\mathrm{Cr}^{3+}$ & $\mathrm{Pb}^{2+}$ \\
\hline $\mathrm{Cd}^{2+}$ & 1.000 & & & & \\
$\mathrm{Zn}^{2+}$ & 0.558 & 1.000 & & & \\
$\mathrm{Ni}^{2+}$ & 0.566 & $0.859^{*}$ & 1.000 & & \\
$\mathrm{Cr}^{3+}$ & 0.263 & 0.636 & $0.760^{*}$ & 1.000 & \\
$\mathrm{~Pb}^{2+}$ & $0.956^{* *}$ & 0.531 & 0.473 & 0.307 & 1.000 \\
\hline
\end{tabular}

*Correlation is significant at the 0.05 level (2-tailed);

**Correlation is significant at the 0.01 level (2-tailed).

The Correlation of the heavy metals in the soil was investigated using a statistical tool, statistical package for social sciences (SPSS) and the result presented in Table 3. The correlation coefficient for pairs of the analyzed elements in the soil revealed positive correlations between all the metals. $\mathrm{Pb}^{2+}, \mathrm{Cd}^{2+}, \mathrm{Ni}^{2+}$, and $\mathrm{Cr}^{3+}$ were significantly correlated. The positive and significant correlations existing among the metals suggest that their presence in the soil arose from common source.

\section{Conclusion}

The results of this study indicate some levels of contamination of the soil around the Gboko Abattoir, Gboko by $\mathrm{Cd}^{2+}, \mathrm{Zn}^{2+}, \mathrm{Ni}^{2+}, \mathrm{Cr}^{3+}$, and $\mathrm{Pb}^{2+}$. However, the levels of these metals were below the maximum permissible limits of $\mathrm{Cd}^{2+} 380 \mathrm{ppm}, \mathrm{Ni}^{2+} 720 \mathrm{ppm}, \mathrm{Cr}^{3+} 240 \mathrm{ppm}$ and $\mathrm{Pb}^{2+} 210 \mathrm{ppm}$ (NDPR) and $\mathrm{Cd}^{2+} 3.0 \mathrm{ppm}, \mathrm{Zn}^{2+} 300 \mathrm{ppm}, \mathrm{Ni}^{2+}$ $75 \mathrm{ppm}, \mathrm{Cr}^{3+} 150 \mathrm{ppm}$ and $\mathrm{Pb}^{2+} 300 \mathrm{ppm}$ set by EU. These results point to the conclusion that the activities in and around the abattoir are contributing to the loading of heavy metals and increase in organic matter in the soils around the abattoir.

\section{Acknowledgements}

The authors wish to thank the staff of NARICT, Zaria, Nigeria for using their facilities.

\section{References}

Adesemoye, A. O., Opere, B. O., \& Makinde, S. C. O. (2006). Microbial Content of abattoir waste water and its contaminated soil in Lagos, Nigeria. African Journal of Biotechnology, 5(20), 1963-1968.

Adriano, D. C. (2003). Trace elements in terrestrial environments: Bioochemistry, Bioavailability and Risk of metals (2nd ed.) (p. 288). New York, USA: Springer.

Agyarko, K., Darteh, E., \& Beringer, B. (2010). Metal levels in some refuse dump soils and plants in Ghana. Journal of plant soil and environment, 56(5), 244-251.

Allen, S. E., Grinshaw, H. W., Pancinson, J. A., \& Quarmby, L. (1974). Chemical Methods of Analyzing Ecological Materials (p. 505). Oxford, London, UK: Blackwell Scientific Publications.

Alloway, B. J., \& Ayres, D. C. (1997). Chemical principles of environmental pollution (2nd ed.) (p. 200-240). Chapman and Hall, London: Blackie Academic and professional.

Alorge, D. O. (1992). Abattoir Design, Management and Effluent Disposal in Nigeria. University of Ibadan Press. 
Bello, Y. O., \& Oyedemi, D. T. A. (2009). The Impact of Abattoir Activities and Management in Residential Neighbourhoods: A Case Study of Ogbomoso, Nigeria. J. Soc. Sci, 19(2), 121-127.

Dara, S. S. (2000). A Textbook of environmental Chemistry and pollution control (pp. 39-42). New Delhi: S. Chand and Company Ltd.

David, N. O., Benjamin, L. K., \& Patrick, O. Y. (2009). Some physiochemical and heavy metal levels in soils of waste dumpsites in Port Harcourt municipality and environs. Journal of applied sciences and environmental management, 13(4), 65-70.

DPR. (2002). Environmental Guidelines and Standards for the Petroleum Industry in Nigeria (EGASPIN). Department of Petroleum Resources (DPR), Lagos, Nigeria.

European Union (EU). (2001). Disposal and recycle routes for sewage sludge. Part I. Sludge Use Acceptance; part II. Regulatory report European Communities, DG Environment Luxemburg: office for official publications of the European Communities. Retrieved from http://www.ec/environment/waste/sludge/sludge_disposal.htm. (10/02/2011)

Ezeoha, S. L., \& Ugwuishiwu, B. O. (2011). Status of Abattoir Wastes Research in Nigeria. Nigerian Journal of Technology, 30(2). 143-148.

Ferner, D. J. (2001). Toxicity, Heavy Metals. Med., 2(5), 1.

Fosmire, G. S. (1990). Zinc Toxicity. Am. J. Clin. Nutr., 51(2), 225-227.

Hornby, A. S. (2006). Oxford Advanced Learner's Dictionary of current English (7th edition) (p. 1381). Oxford University Press.

Ibitoye, A. A. (2006). Laboratory Manual on Basic Soil Analysis (pp. 16-36). Foladave Nigeria Ltd.

Jukna, C., Jukna, V., \& Suigzdaite, J. (2006). Determination of Heavy metals in Viscera and Muscles of cattle. Bulgarian Journal of Veterinary Medicine, 9(1), 35-41.

Katarzyna, R. A., Monkiewicz, J., \& Andrzej, G. (2009). Lead, cadmium, arsenic, copper and zinc contents in hair of cattle living in the area contaminated by a copper smelter in 2006-2008. Bull Vet Inst Pulawy, 53, 703-706.

Kruslin, E., Hodel, C. M., \& Schurgast, H. (1999). Progress in diagnosis of Chronic Toxic metal Poisoning by Hair analysis. Toxicol. Lett., 88, 84. http://dx.doi.org/10.1016/S0378-4274(96)80302-X

Mohammed, S, \& Musa, J. J. (2012). Impact of Abattoir Effluent on River Landzu, Bida, Nigeria. Journal of Chemical, Biological and Physical Sciences, 2(1), 132-136.

Natural Resources Conservation Service (NRCS). (2011). Use of Reaction (pH) in Soil Taxonomy. Retrieved from http://soils.usda.gov/technical/technotes/note8.html

Nwachukwu, M. I., Akinde, S. B., Udujih, O. S., \& Nwachukwu, I. O. (2011). Effect of abattoir wastes on the population of proteolytic and lipolytic bacteria in a Recipient Water Body (Otamiri River). Global Research Journal of Science, 1, 40-42.

Odoemelan, S. A., \& Ajunwa, O. (2008). Heavy Metal Status and Physicochemical Properties of Agricultural Soil amended by short term application of animal manure. Journal of Chemical Society of Nigeria, 30, 60-63.

Okoronkwo, N. E., Odemelan, S. A., \& Ano, O. A. (2006). Levels of toxic elements in soils of abandoned waste dump in cities. African Journal of Biotechnology, 5(13), 1241-1244. Retrieved from http://www.academicjournals.org/ABJ

Olanike, K. A. (2002). Unhygienic operation of a city abattoir in south western Nigeria: Environmental implication. AJEAM/RAGEE, 4(1), 23-28.

Patra, R. C., Swarup, D., Naresh, R., Kumar, P., Nandi, D., Shekhar, P., ... Ali, S. L. (2007). Tail hair as an indicator of environmental exposure of cows to lead and cadmium in different industrial areas. Ecotoxicol Environ., Saf., 66, 127-131. http://dx.doi.org/10.1016/j.ecoenv.2006.01.005

Red Meat Abbattoir Association. (2010). Waste Management-Red Meat Abattoir. Retrieved from http://www.docstoc.com/docs/103302144/Waste-Management-\%EE\%9F\%A6-Red-Meat-Abattoirs

Steffen, Roberts and Kirsten Inc. (1989). Water and waste-water management in the red meat industry (pp. 36). WRC Report No. 145 TT41/89. WRC, Pretoria. 
Walkley, A., \& Black, C. A. (1934). An Examination of the Degtjareff Method for Determining Soil Organic Matter, and A Proposed Modification of the Chromic Acid Titration Method. Soil Science, $37,29$. http://dx.doi.org/10.1097/00010694-193401000-00003 